\title{
A Systematic Review of Empirical Studies on Participants' Interactions in Internet-Mediated Discussion Boards as a Course Component in Formal Higher Education Settings
}

\author{
Hong Zhou \\ University of Texas at San Antonio
}

\begin{abstract}
This systematic review and synthesis of existing empirical studies examines peer-reviewed research articles published between January 2000 and May 2014 on the use of Internet-mediated discussion boards in higher education settings with a specific interest in the participants' interactions. Forty-two primary studies were examined after a systematic search and full text review. The findings from the primary studies regarding participants' interactions were analyzed using constant comparison coding techniques. The analysis and its results indicate several potential directions for future research, and connect the primary studies to provide a more holistic understanding of the participants' interactions in Internetmediated discussions in the higher education setting.
\end{abstract}

\section{Introduction}

The research regarding online discussion in higher education settings has developed substantially since the 1990s. Learning and teaching in Internet-mediated discussions has been examined in many studies, with foci including participation (Brooks \& Bippus, 2012; Topper, 2005), experiences (Gerbic, 2006; Milman, Hillarious, \& Walker, 2012), interactions (Çelik, 2013; Light, Nesbitt, Light, \& Burns, 2000), community building (Guilar \& Loring, 2008; Lee, Carterwells, Glaeser, \& Ivers, 2006), learning 
outcomes (Zhan, Xu, \& Ye, 2011), identities (Bryce, 2007), gender differences (Cheng, Liu, Chen, Shih, \& Chang, 2012). Contexts have included distance education (Exter, Korkmaz, Harlin, \& Bichelmeyer, 2009; Shackelford \& Maxwell, 2012), professional development (Ekong, 2006), and accredited college courses (Lapadat, 2007). As course management systems and learning management systems become commonplace in colleges and universities, Internet-mediated discussions are increasingly utilized to supplement courses in higher education settings. Consequently, the appropriate and meaningful use of such tools has significant educational and fiscal implications.

\section{Purpose of Review and Research Questions}

As Internet-mediated discussion gains popularity within higher education and attention from researchers, the number of studies on this topic has also grown rapidly to cover various aspects such as contexts, perspectives, and participant groups. The diversity among the foci of the studies is significant, but together as a group these studies have covered many aspects to be researched. This accumulated knowledge has provided a solid foundation for a more holistic representation of Internet-mediated discussion as part of higher education course settings. However, an extensive search for studies on this topic yielded many results in examining some specific aspects of the participants' interaction, some studies quantitatively analyzing the effectiveness of some contributing factors affecting the participants' interaction, and some reviews of literature describing the interaction patterns, but no empirical-based study describing an overall understanding of the phenomenon. The main objective of this systematic review is to fill this gap by constructing a comprehensive understanding toward participants' interactions in Internet-mediated discussion when such discussions were utilized as components of formal courses in higher education settings. The questions guiding this review are:

1. What groups of participants have been studied for their interactions in online discussion?

2. What are the methods applied in studying the participants' interactions?

3. What have the existing studies found about the participants' interactions?

4. How do these findings connect with each other to form a holistic representation of the participants' interactions?

\section{Key Concepts}

Before delving into these research questions, it is necessary to clarify several key concepts based on past and current literature. The common understanding of discussion is a conversation or exchange of information on given topics. Thurlow, Lengel, \& Tomic's (2004) widely accepted definition of computer-mediated communication describes it as "a process of human communication via computers, involving people, situated in particular contexts, engaging in processes to shape media for a variety of purposes” (p.15). Based on this definition and extending the context to the Internet, Internet-mediated discussion can be viewed as computer-mediated exchange of information that occurs only on the Internet under a hierarchical structure. For the purpose of this review, an Internet-mediated discussion forum is defined as a virtual platform for people to exchange information on given topics in a hierarchical or threaded structure. More specifically, it is situated in the context of coursework in higher education settings for the purpose of fulfilling the requirements of the course. Communication includes both sending and receiving information, and the Internet-mediated discussion forum supports both.

The term "participation" is largely understood as "being part of," referring to the voluntary presence in an environment, with or without further actions involving other humans or objects. In this review, the term "participation" is defined as presence in the Internet-mediated discussion, including both voluntary and mandatory presence under the course requirements.

Interactions have been defined as "reciprocal events that require at least two objects and two actions," and they "occur when these objects and events mutually influence one another” (Wagner, 1994, 
p. 8). In the context of computer-mediated environments, the meaning of "objects" expands to include the computers, the human beings operating the computers, the platform supporting the reciprocal events, and the content produced during such events. For example, one person writing an email to another person is one action involving multiple objects, thus not an interaction; however, once the recipient reads this email, another action is carried out, and an interaction is formed. Since the focus of this review is Internet-mediated discussion, interaction is defined here as an event involving two parties' actions, including both reading and posting messages during online discussions. This review follows the wellaccepted model of interaction in distance learning proposed by Moore (1989) in which interactions are categorized as student-student, student-teacher, and student-content. The learner-interface interaction proposed by Hillman, Willis, and Gunawardena (1994) is also included because of its relevance to this review's area of focus.

For the purpose of this review, participation and interaction are both viewed as part of communication with distinguishing differences. One instance of interaction must involve the participation of at least two parties each carrying out at least one action. When one party sends information, this action is part of the communication; however, without another party's response, this first action is considered as an instance of participation by the first party, which may or may not generate interaction. Once a response occurs, an instance of interaction is achieved.

\section{Inclusion Criteria}

\section{Methodology}

This review included studies conducted since 2000 with an interest in participants' interactions in Internet-mediated discussion boards in higher education settings. Eligible studies included those conducted within higher education settings, with the participants taking formal courses using Internetmediated discussion as part of the coursework, and with findings including quantitative or qualitative analyses of at least one aspect of participants' interactions.

Eight criteria were considered for inclusion of the primary studies:

1. Publication date: from January 2000 to May 2014

2. Publication type: peer-reviewed journal articles

3. Language of publication: English

4. Setting of study: accredited courses in higher education

5. Utilization of online discussion: part of coursework, synchronous or asynchronous

6. Participants: students (undergraduate and graduate), with or without data regarding the instructor

7. Key terms definition alignment: the definition or description of the key terms - computermediated communication, Internet-mediated discussion, participation, and interaction, align with the conceptual definition used for this study

8. Qualifying findings of study: some aspects of the interactions involving the participants reported in the findings

\section{Search Strategy}

Studies were located for this review via two steps:

- A key word search in the electronic databases of ERIC, Education Abstracts Full Text, PsycInfo, Social Science Citations Index, Academic Search Complete, ScienceDirect, and Google scholar (Table 1).

- A manual review of the reference lists of the literature review articles on similar topics and the reference lists of the primary studies located via the first step. 
A Systematic Review of Empirical Studies on Participants' Interactions on Internet-Mediated Discussion Board as Course Component in Formal Higher Education Settings

Table 1 Electronic database and search terms

\begin{tabular}{|c|c|c|}
\hline Database & Search terms & Other search filters \\
\hline ERIC via EBSCO & $\begin{array}{l}\text { (college OR universit* OR "higher education" } \\
\text { OR * } \quad \text { *graduate) } \\
\text { AND } \\
\text { (online OR Internet OR “computer-mediated } \\
\text { communication" OR CMC) in title } \\
\text { AND (discussion AND participant) in text }\end{array}$ & $\begin{array}{l}\text { Date published from: January } 2000 \\
\text { - May } 2014 \\
\text { Educational level: Higher Education }\end{array}$ \\
\hline $\begin{array}{l}\text { Education Full Text via } \\
\text { EBSCO }\end{array}$ & $\begin{array}{l}\text { (college OR universit* OR "higher education" } \\
\text { OR } \quad \text { *graduate) } \\
\text { AND } \\
\text { (online OR Internet OR “computer-mediated } \\
\text { communication" OR CMC) in title } \\
\text { AND (discussion AND participant) in text }\end{array}$ & $\begin{array}{l}\text { Date published from: January } 2000 \\
\text { - May } 2014\end{array}$ \\
\hline Web of Science (SSCI) & 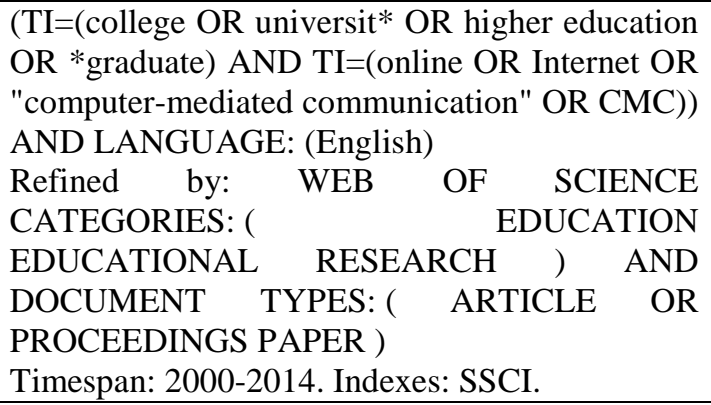 & $\begin{array}{l}\text { Date published from: January } 2000 \\
\text { - May 2014, } \\
\\
\text { Limit to } \\
\text { Social Sciences Citation Index } \\
\text { (SSCI) }\end{array}$ \\
\hline $\begin{array}{l}\text { Academic Search } \\
\text { Complete via EBSCO }\end{array}$ & $\begin{array}{l}\text { (college OR universit* OR "higher education" } \\
\text { OR } \quad \text { *graduate) in } \\
\text { AND } \\
\text { (online OR Internet OR “computer-mediated } \\
\text { communication" OR CMC) in title } \\
\text { AND (discussion AND participant AND course) } \\
\text { in text }\end{array}$ & $\begin{array}{l}\text { Date published from: January } 2000 \\
\text { - May 2014, } \\
\text { Language: English } \\
\text { limit: Peer Reviewed Journal }\end{array}$ \\
\hline PsychINFO via Ovid & $\begin{array}{l}\text { ((college or universit or higher education or } \\
\text { graduate) and (online or Internet or computer } \\
\text { mediated communication or CMC)).ti. and } \\
\text { course.ab. }\end{array}$ & $\begin{array}{l}\text { Publication year: } 2000 \text { - 2014, } \\
\text { Languages: English, } \\
\text { limit: Peer Reviewed Journal }\end{array}$ \\
\hline ScienceDirect & $\begin{array}{l}\text { (college OR universit* OR "higher education" } \\
\text { OR *graduate) in } \\
\text { AND } \\
\text { (online OR Internet OR “computer-mediated } \\
\text { communication" OR CMC) in title } \\
\text { AND (discussion, participant, course) in } \\
\text { Abstract, Title, or Keywords } \\
\end{array}$ & $\begin{array}{l}\text { Publication year: } 2000-2014 \text {, } \\
\text { limit: Computer Science, Social } \\
\text { Science, Journal article }\end{array}$ \\
\hline Google scholar & $\begin{array}{l}\text { search article title for all words in one of these } \\
\text { groups: } \\
\text { "higher education" + online + discussion } \\
\text { "higher education" + Internet + discussion } \\
\text { "higher education" + "computer-mediated } \\
\text { communication" } \\
\text { College + online + discussion } \\
\text { College + Internet + discussion } \\
\text { College + "computer-mediated communication" } \\
\text { Universit + online + discussion } \\
\text { Universit + Internet + discussion } \\
\text { Universit + computer-mediated communication }\end{array}$ & Date published from: $2000-2014$ \\
\hline
\end{tabular}


Table 2 Constant comparison matrix (partial)

\begin{tabular}{|c|c|c|c|c|c|}
\hline Study & methodology & setting & participants & main findings & analytical tool \\
\hline 6 & $\begin{array}{l}\text { case study, } \\
\text { coding } \\
\text { system based } \\
\text { on previous } \\
\text { studies }\end{array}$ & $\begin{array}{l}\text { 10-week course, } \\
\text { eLearning design } \\
\text { topic, online } \\
\text { Master's program, } \\
\text { instructor provide } \\
\text { weekly topics, } \\
20 \% \text { of final grade }\end{array}$ & $\begin{array}{l}16 \text { graduate } \\
\text { students, }\end{array}$ & $\begin{array}{l}\text { significant difference between the overall } \\
\text { and weekly learner-learner and learner- } \\
\text { instructor interaction levels; no significant } \\
\text { difference on learners' interaction level } \\
\text { from all paired comparisons; Interaction } \\
\text { level between learners and the instructor } \\
\text { significant decreasing from Week 1-8. }\end{array}$ & $\begin{array}{l}\text { survey with } \\
\text { modification for } \\
\text { inquiry on } \\
\text { interaction } \\
\text { level, 7-point } \\
\text { Likert scale; }\end{array}$ \\
\hline 8 & $\begin{array}{l}\text { case study, } \\
\text { descriptive } \\
\text { analysis at } \\
\text { group level, }\end{array}$ & $\begin{array}{l}\text { undergraduate } \\
\text { course, UK, } \\
\text { weekly lecture, } \\
\text { tutor set up } \\
\text { discussion and } \\
\text { posted one articles } \\
\text { for open group } \\
\text { discussions } \\
\text { students had } 5 \\
\text { weeks to respond }\end{array}$ & $\begin{array}{l}\text { 10female } \\
\text { 19male, } \\
\text { third year } \\
\text { undergradua } \\
\text { te }\end{array}$ & $\begin{array}{l}\text { students' strong tendency to address } \\
\text { contributions to the tutor; good deal of off- } \\
\text { task communications and personal abuse } \\
\text { without tutor; disruption occurred in all } 4 \\
\text { groups; different interactive levels among } \\
\text { groups; netiquette as social rules }\end{array}$ & $\begin{array}{l}\text { post frequency } \\
\text { counts, task- } \\
\text { focus vs. } \\
\text { partial-focus vs. } \\
\text { off-task, }\end{array}$ \\
\hline 9 & $\begin{array}{l}\text { qualitative, } \\
\text { coding, } \\
\text { quantifying } \\
\text { counts of } \\
\text { codes }\end{array}$ & $\begin{array}{l}\text { online course, } \\
\text { group of three, } \\
\text { project-based, } \\
\text { assigned group } \\
\text { leader, required } \\
\text { posts }\end{array}$ & $\begin{array}{l}\text { graduate } \\
\text { students, } \\
\text { 10male } \\
\text { 20female }\end{array}$ & $\begin{array}{l}\text { most frequent interaction type is mutually } \\
\text { constructing knowledge; students rarely } \\
\text { challenge others; all collaborative } \\
\text { interactions in face-to-face situations are } \\
\text { identified in synchronous discussion }\end{array}$ & $\begin{array}{l}\text { eight types of } \\
\text { collaborative } \\
\text { interactions }\end{array}$ \\
\hline 10 & $\begin{array}{l}\text { quantitative, } \\
\text { DV=SoC } \\
\text { (sense of } \\
\text { community), } \\
\text { SPSS, Chi- } \\
\text { square, } \\
\text { correlations, } \\
\text { regression, }\end{array}$ & $\begin{array}{l}\text { South Central } \\
\text { U.S., online } \\
\text { graduate course, }\end{array}$ & $\mathrm{n}=381$ & $\begin{array}{l}\text { All interaction items were fairly to } \\
\text { moderately correlated, with higher CCS } \\
\text { total scores; learner-learner interactions } \\
\text { regression model was significant ( } \mathrm{F}= \\
62.861, \mathrm{p}<.05, \mathrm{R} 246 \%) \text { by the five } \\
\text { predictors; the other items were excluded } \\
\text { from the model due to their non-significant } \\
\text { impact; for each type of learner-learner } \\
\text { interaction, frequency was significantly } \\
\text { related to importance; for all types of } \\
\text { interaction, the relationship was positive in } \\
\text { direction. }\end{array}$ & $\begin{array}{l}\text { classroom } \\
\text { community } \\
\text { scale; nine } \\
\text { learner-learner } \\
\text { interactions }\end{array}$ \\
\hline 11 & $\begin{array}{l}\text { content } \\
\text { analysis }\end{array}$ & $\begin{array}{l}\text { two graduate } \\
\text { courses, hybrid, } \\
\text { group discussion, } \\
\text { group project, }\end{array}$ & $\begin{array}{l}\text { graduate } \\
\text { students, } \\
\text { curriculum } \\
\text { and } \\
\text { instruction } \\
\text { (Midwest } \\
\text { Case) and } \\
\text { the other in } \\
\text { counseling } \\
\text { (Southeast } \\
\text { Case) }\end{array}$ & $\begin{array}{l}\text { initiating and supporting communication } \\
\text { patterns dominated the online discussions; } \\
\text { challenging and monitoring patterns were } \\
\text { exhibited lower overall; summarizing } \\
\text { occurred in only one of the cases; responses } \\
\text { to a posting patterns of interaction were } \\
\text { high in both cases; reply to a response } \\
\text { patterns tended to be lower in occurrence } \\
\text { compared to RP patterns; only in the } \\
\text { Southeast case did students use level } 4 \\
\text { replies; certain topics seemed to generate } \\
\text { higher levels of interactivity; time to } \\
\text { complete an activity or discussion affected } \\
\text { the interaction patterns with a positive } \\
\text { relationship between level of interaction and } \\
\text { time }\end{array}$ & $\begin{array}{l}\text { categories of } \\
\text { communication } \\
\text { interaction level }\end{array}$ \\
\hline
\end{tabular}


The search yielded 514 articles. The titles and abstracts of these articles were reviewed to eliminate articles not fitting the inclusion criteria. The most common exclusions were articles reporting the development or evaluation of Internet-mediated learning management systems in higher education settings. Some articles were excluded because they have "online" and "higher education" in the title but do not report students' participation in online discussion forums. Other studies reporting computermediated communications in higher education settings but not as part of a course were also excluded. Of the remaining 116 articles, 26 were duplicates from multiple electronic databases, and were removed from the list. The abstracts and full texts of the remaining 90 studies were obtained and evaluated using the inclusion criteria. After a closer examination of the full text, 42 studies meeting all inclusive criteria were included in this review.

\section{Analytic Procedure}

All primary studies were examined for their findings and the contexts in which they were conducted.. Constant comparison was the main approach to this examination and synthesis. Constant comparison is "an analytic process of comparing different pieces of data for similarities and differences" (Corbin \& Strauss, 2008, p.65) commonly applied to analyzing data of a qualitative nature. Taking this approach, all primary findings were extracted and listed in a matrix (partially shown in Table 2) along with the various aspects of the context where each study was conducted. These aspects include the setting of the study, the demographic of the participants, the data collecting and analysis instruments used, and the data analysis methods.

Each primary finding was compared to all other primary findings in an attempt to identify the similarities and/or differences among them. Conceptually similar primary findings were grouped together under a broader description. For example, a primary finding from one study reported having 31 posts for the semester and 15 of them came from one participant (Gerbic, 2006); another study reported a few students dominating the discussion (Giannini-Gachago \& Seleka, 2005); and another study reported that in the online discussion 19 students posted $20-50$ posts, one posted nine, and three posted 60 and above (Picciano, 2002). These three primary findings are similar in that they all describe that a small number of participants dominated the discussion. Therefore, a broader concept of "a few students dominate the discussion" is established to describe one of the characteristics of the online discussion.

Although each the primary finding was compared to the others, not all of them are reported in the synthesis. Since the main objective of this review is to construct a comprehensive understanding of the participants' interactions in general, only traits that are reflected in multiple primary findings are considered potential candidates for further generalization. A characteristic of the online discussion reflected in more primary findings is considered stronger than a characteristic reflected in fewer primary findings. Many primary findings are unique to the reporting study, thus not considered as part of the general understanding of participants' interactions in online discussion.

\section{Findings and Discussion}

The primary findings were examined as well as the context in which the study was conducted. Variables including the setting, participants, and instruments were compared across multiple primary studies. The findings from this review and synthesis are reported in the nextsection addressing each of the guiding questions.

\section{Groups of Participants Studied}

The first question guiding this review asks about participant groups that have been studied. The findings are as follows. The 42 primary studies were conducted in eight countries, representing cultures from both developed and developing nations in North America, Africa, Europe, and Asia. Twenty studies 
were conducted in the United States, and the others in Australia, Botswana, Canada, China, South Korea, Turkey, and the United Kingdom. These studies were conducted in various settings including traditional residential campuses, virtual universities, and face-to-face courses with supplemental online components. Such broad diversity adds to the validity of the findings from this synthesis of literature.

Within the 42 primary studies, three did not specify whether the participants were undergraduate or graduate students. Of the 39 studies reporting participants' academic levels, 24 were conducted with graduate participants, and 15 were conducted with undergraduate participants.

Courses that employed Internet-mediated discussion were specified in 30 studies, and ranged across the fields of business, communication, digital design, education, environmental studies, healthcare, information science, journaling, liberal arts, literacy, mathematics, organizational behavior, psychology, social science, and technology (see Table 3). The most heavily represented field of study was education which was reported in thirteen studies, while 22 studies were conducted in various disciplines in the social sciences. Communication and technology courses were each reported in three studies. Healthcare and mathematics were reported in only one study each, while some popular academic disciplines were not represented at all, such as law, the arts, political science, and engineering. Such distribution could be interpreted in two ways, either the Internet-mediated discussion component has not been widely applied in certain academic disciplines in higher education settings, or researchers have not paid adequate attention to certain areas.

Table 3 Summary of participants, environments, and methodologies of the primary studies

\begin{tabular}{|c|c|c|c|c|c|}
\hline Authors & Year & Methodology & $\begin{array}{l}\text { Course \& Field } \\
\text { of Study }\end{array}$ & Country & Participants \\
\hline $\begin{array}{l}\text { Ahern, T. C. \& El- } \\
\text { Hindi, A. E. }\end{array}$ & 2000 & $\begin{array}{l}\text { quantitative, } \\
\text { qualitative }\end{array}$ & $\begin{array}{l}\text { learning and } \\
\text { instructional } \\
\text { theory } \\
\text { education }\end{array}$ & $\mathrm{n} / \mathrm{a}$ & $\begin{array}{l}\text { post } \\
\text { baccalaureate }\end{array}$ \\
\hline $\begin{array}{l}\text { Davidson-Shivers, } \\
\text { V., Luyegu, E., } \\
\text { Kimble, B. E. }\end{array}$ & 2000 & descriptive & $\mathrm{n} / \mathrm{a}$ & U.S. & graduate \\
\hline $\begin{array}{l}\text { Light, V., Nesbitt, E., } \\
\text { Light, P., \& Burns, J. R. }\end{array}$ & 2000 & $\begin{array}{ll}\text { case } & \text { study, } \\
\text { descriptive } & \\
\text { analysis } & \\
\end{array}$ & $\begin{array}{l}\text { communication / } \\
\text { communication }\end{array}$ & $\overline{\mathrm{UK}}$ & undergraduate \\
\hline Poole, D. M. & 2000 & qualitative & $\begin{array}{l}\text { social } \\
\text { perspectives of } \\
\text { technology } \\
\text { education } \\
\text { education }\end{array}$ & U.S. & graduate \\
\hline $\begin{array}{l}\text { Larson, B. E. \& T. A. } \\
\text { Keiper }\end{array}$ & 2002 & $\begin{array}{l}\text { qualitative, } \\
\text { constant } \\
\text { comparison }\end{array}$ & $\begin{array}{lr}\text { social } & \text { studies } \\
\text { methods } & \text { / Social } \\
\text { science } & \\
\end{array}$ & U.S. & $\mathrm{n} / \mathrm{a}$ \\
\hline $\begin{array}{l}\text { Mäkitalo, K., Häkkinen, } \\
\text { P., Leinonen, P., \& } \\
\text { Järvelä, S. }\end{array}$ & 2002 & qualitative & $\mathrm{n} / \mathrm{a}$ & Finland & $\begin{array}{l}\text { Pre-service } \\
\text { teachers }\end{array}$ \\
\hline Picciano, A. G. & 2002 & descriptive analysis & $\begin{array}{l}\text { education } \\
\text { administration } \\
\text { education }\end{array}$ & U.S. & graduate \\
\hline Thomas, M. J. W. & 2002 & $\begin{array}{l}\text { quantitative, } \\
\text { qualitative, content } \\
\text { analysis }\end{array}$ & $\begin{array}{l}\text { Environmental } \\
\text { Studies } \\
\text { Environmental }\end{array}$ & $\mathrm{n} / \mathrm{a}$ & undergraduate \\
\hline
\end{tabular}


A Systematic Review of Empirical Studies on Participants' Interactions on Internet-Mediated Discussion Board as Course Component in Formal Higher Education Settings

\begin{tabular}{|c|c|c|c|c|c|}
\hline & & & Studies & & \\
\hline Cifuentes, L. J. & 2003 & quantitative & $\begin{array}{l}\text { educational } \\
\text { technology } \\
\text { education }\end{array}$ & $\mathrm{n} / \mathrm{a}$ & undergraduate \\
\hline Jeong, A. C. & 2003 & content analysis & $\begin{array}{l}\text { Business Ethics / } \\
\text { Business }\end{array}$ & U.S. & graduate \\
\hline Lee, J. \& C. C. Gibson & 2003 & $\begin{array}{l}\text { quantitative, } \\
\text { qualitative, content } \\
\text { analysis }\end{array}$ & $\begin{array}{lr}\text { adult } & \text { distance } \\
\text { learning } & / \\
\text { education } & \end{array}$ & $\mathrm{n} / \mathrm{a}$ & graduate \\
\hline $\begin{array}{l}\text { Pilkington, } \quad \text { R. } \quad \text { M., } \quad \text { \& } \\
\text { Walker, S. A. }\end{array}$ & 2003 & $\begin{array}{l}\text { descriptive, } \\
\text { qualitative }\end{array}$ & $\begin{array}{ll}\text { education } \\
\text { education }\end{array}$ & $\mathrm{n} / \mathrm{a}$ & graduate \\
\hline $\begin{array}{l}\text { Christopher, } \quad \text { M. M., } \\
\text { Thomas, J. A., \& Tallent- } \\
\text { Runnels, M. K. }\end{array}$ & 2004 & $\begin{array}{l}\text { naturalistic inquiry, } \\
\text { qualitative }\end{array}$ & $\begin{array}{l}\text { social and } \\
\text { emotional needs of } \\
\text { gifted learners / } \\
\text { education }\end{array}$ & U.S. & graduate \\
\hline $\begin{array}{l}\text { Cunningham-Atkins, } \\
\text { Powell, N., Moore, D., } \\
\text { Hobbs, D., \& Sharpe, S. }\end{array}$ & 2004 & quantitative & $\begin{array}{l}\text { technology courses } \\
/ \quad \text { technology } \\
\text { courses }\end{array}$ & UK & undergraduate \\
\hline Im, Y. L. & 2004 & $\begin{array}{l}\text { quantitative, } \\
\text { descriptive }\end{array}$ & $\begin{array}{l}\text { pedagogy of web- } \\
\text { based instruction / } \\
\text { education }\end{array}$ & $\begin{array}{l}\text { South } \\
\text { Korea }\end{array}$ & $\mathrm{n} / \mathrm{a}$ \\
\hline $\begin{array}{l}\text { Sorensen, Christine K. \& } \\
\text { Baylen, Danilo M. }\end{array}$ & 2004 & content analysis & $\mathrm{n} / \mathrm{a}$ & U.S. & graduate \\
\hline Brannan, T. A. & 2005 & $\begin{array}{l}\text { quantitative, } \\
\text { qualitative }\end{array}$ & $\mathrm{n} / \mathrm{a}$ & U.S. & $\mathrm{n} / \mathrm{a}$ \\
\hline \begin{tabular}{l}
\multicolumn{3}{l}{ Giannini-Gachago, } \\
Daniela \& \\
Geoffrey
\end{tabular} & 2005 & $\begin{array}{l}\text { quantitative, t-test; } \\
\text { qualitative, content } \\
\text { analysis }\end{array}$ & $\mathrm{n} / \mathrm{a}$ & Botswana & graduate \\
\hline $\begin{array}{l}\text { Lobel, M., Neubauer, M., } \\
\text { \& Swedburg, R. }\end{array}$ & 2005 & qualitative & $\begin{array}{l}\text { interpersonal } \\
\text { communication } \\
\text { and relationships / } \\
\text { communication }\end{array}$ & Canada & undergraduate \\
\hline Dawson, S. & 2006 & quantitative & $\begin{array}{l}\text { education } \\
\text { discipline } \\
\text { education }\end{array}$ & Australia & $\begin{array}{l}\text { undergraduate, } \\
\text { graduate }\end{array}$ \\
\hline $\begin{array}{l}\text { Ellis, R. A., Goodyear, P., } \\
\text { Prosser, M., \& O'Hara, A. }\end{array}$ & 2006 & $\begin{array}{l}\text { qualitative, } \\
\text { descriptive }\end{array}$ & $\begin{array}{l}\text { psychology } \\
\text { psychology }\end{array}$ & Australia & undergraduate \\
\hline Gerbic, P. & 2006 & case study & $\begin{array}{lll}\text { business } & \text { law } \\
\text { business } & & \\
\end{array}$ & Australia & undergraduate \\
\hline $\begin{array}{l}\text { Lee, J., Carter-Wells, J., } \\
\text { Glaeser, B., Ivers, K., \& } \\
\text { Street, C. }\end{array}$ & 2006 & $\begin{array}{l}\text { longitudinal case } \\
\text { study }\end{array}$ & $\mathrm{n} / \mathrm{a}$ & U.S. & graduate \\
\hline Bryce, N. & 2007 & discourse analysis & journaling / literacy & U.S. & graduate \\
\hline Fernandez, Maria L. & 2007 & $\begin{array}{l}\text { discourse analysis; } \\
\text { quantitative }\end{array}$ & $\begin{array}{l}\text { multicultural } \\
\text { mathematics } \\
\text { education } \\
\text { education } \\
\end{array}$ & $\mathrm{n} / \mathrm{a}$ & graduate \\
\hline Lapadat, Judith C. & 2007 & $\begin{array}{l}\text { case study, } \\
\text { discourse analysis }\end{array}$ & $\mathrm{n} / \mathrm{a}$ & Canada & graduate \\
\hline
\end{tabular}


A Systematic Review of Empirical Studies on Participants' Interactions on Internet-Mediated Discussion Board as Course Component in Formal Higher Education Settings

\begin{tabular}{|c|c|c|c|c|c|}
\hline $\begin{array}{l}\text { Maushak, Nancy J. \& Ou, } \\
\text { Chaohua }\end{array}$ & 2007 & $\begin{array}{l}\text { qualitative, } \\
\text { quantifying counts } \\
\text { of codes }\end{array}$ & $\mathrm{n} / \mathrm{a}$ & U.S. & graduate \\
\hline $\begin{array}{l}\text { Campbell, M., Gibson, W., } \\
\text { Hall, A., Richards, D., \& } \\
\text { Callery, P. }\end{array}$ & 2008 & $\begin{array}{l}\text { quasi-experimental, } \\
\text { quantitative }\end{array}$ & $\begin{array}{l}\text { healthcare research } \\
\text { methods } \\
\text { healthcare }\end{array}$ & UK & postgraduate \\
\hline $\begin{array}{l}\text { Exter, M. E., Korkmaz, N., } \\
\text { Harlin, N. M., \& } \\
\text { Bichelmeyer, B. A. }\end{array}$ & 2009 & $\begin{array}{l}\text { quantitative, t-test, } \\
\text { qualitative interview }\end{array}$ & $\begin{array}{l}\text { multiple courses } \\
\text { multiple courses }\end{array}$ & U.S. & graduate \\
\hline $\begin{array}{l}\text { Huang, Wen-Hao David \& } \\
\text { Nakazawa, Kazuaki }\end{array}$ & 2010 & case study & $\begin{array}{l}\text { elearning } \\
\text { education }\end{array}$ & U.S. & graduate \\
\hline Morris, T. A. & 2010 & qualitative & $\begin{array}{l}\text { liberal arts, social } \\
\text { science, } \\
\text { information } \\
\text { liberal arts, social } \\
\text { science, } \\
\text { information }\end{array}$ & U.S. & undergraduate \\
\hline Xie, Kui \& Ke, F. & 2011 & $\begin{array}{l}\text { quantitative, } \\
\text { qualitative, content } \\
\text { analysis }\end{array}$ & IST / education & U.S. & $\mathrm{n} / \mathrm{a}$ \\
\hline $\begin{array}{l}\text { Zhan, Z. H., Xu, F. Y., \& } \\
\text { Ye, H. W. }\end{array}$ & 2011 & $\begin{array}{l}\text { quantitative, t-test, } \\
\text { MANOVA, } \\
\text { ANOVA }\end{array}$ & $\begin{array}{l}\text { digital design } \\
\text { digital design }\end{array}$ & China & undergraduate \\
\hline $\begin{array}{l}\text { Brooks, Catherine F. \& } \\
\text { Bippus, Amy M. }\end{array}$ & 2012 & $\begin{array}{l}\text { qualitative, case } \\
\text { study }\end{array}$ & $\begin{array}{l}\text { communication } \\
\text { communication }\end{array}$ & $\mathrm{n} / \mathrm{a}$ & undergraduate \\
\hline $\begin{array}{l}\text { Cheng, S. S., Liu, E. Z. F., } \\
\text { Chen, N. S., Shih, R. C., \& } \\
\text { Chang, C. S. }\end{array}$ & 2012 & quantitative & $\begin{array}{l}\text { English test prep / } \\
\text { literacy }\end{array}$ & China & undergraduate \\
\hline $\begin{array}{llll}\text { Du, Jianxia } & \& & \mathrm{Xu} \\
\text { Jianzhong } & & \end{array}$ & 2012 & descriptive stats & $\begin{array}{l}\text { multimedia and } \\
\text { hypermedia design } \\
\text { / digital design }\end{array}$ & U.S. & graduate \\
\hline $\begin{array}{llll}\text { Shackelford, } & \text { J. } & \text { L. } \quad \text { \& } \\
\text { Maxwell, M. } & & & \end{array}$ & 2012 & $\begin{array}{l}\text { quantitative, Chi- } \\
\text { sq, correlations, } \\
\text { regression, }\end{array}$ & $\mathrm{n} / \mathrm{a}$ & U.S. & graduate \\
\hline $\begin{array}{l}\text { Wise, A. F., Perera, N., } \\
\text { Hsiao, Y. T., Speer, J., \& } \\
\text { Marbouti, F. }\end{array}$ & 2012 & $\begin{array}{l}\text { micro analytic case } \\
\text { study, descriptive }\end{array}$ & $\begin{array}{l}\text { organizational } \\
\text { behavior } \\
\text { organizational } \\
\text { behavior }\end{array}$ & Canada & undergraduate \\
\hline Wuttikietpaiboon, K. & 2012 & $\begin{array}{l}\text { case study, content } \\
\text { analysis }\end{array}$ & literacy / literacy & U.S. & graduate \\
\hline $\begin{array}{l}\text { Akarasriworn, C., \& Ku, } \\
\text { H. }\end{array}$ & 2013 & quantitative & $\begin{array}{l}\text { mathematics } \\
\text { modeling / } \\
\text { mathematics } \\
\text { modeling }\end{array}$ & U.S. & graduate \\
\hline Çelik, Servet & 2013 & $\begin{array}{ll}\text { discourse; } & \text { lexis } \\
\text { analysis } & \end{array}$ & $\begin{array}{l}\text { English Language } \\
\text { teaching methods / } \\
\text { education }\end{array}$ & Turkey & graduate \\
\hline $\begin{array}{l}\text { Xie, K., Yu, C., } \quad \& \\
\text { Bradshaw, A. C. }\end{array}$ & 2014 & \begin{tabular}{l}
\multicolumn{2}{l}{ quantitative, } \\
learning analytics, \\
social network \\
analysis, qualitative
\end{tabular} & $\mathrm{n} / \mathrm{a}$ & U.S. & undergraduate \\
\hline
\end{tabular}


A Systematic Review of Empirical Studies on Participants' Interactions on Internet-Mediated Discussion Board as Course Component in Formal Higher Education Settings

\section{Methods Applied}

The second question asks about methods applied in the included studies. As shown in Table 3, nine of the 42 studies used only quantitative methods, sixteen used only qualitative methods, and 17 used both quantitative and qualitative methods. A closer examination revealed the most commonly used forms of quantitative analyses to be t-tests, analysis of variance, and regression modeling; the most frequent methods of qualitative analyses included content analysis, case studies, and discourse analysis.

In these 42 studies, quantitative methods were applied to examine gender differences in online behaviors (Cheng et al., 2012), major source of engagement (Morris, 2010), various levels of participation (Cunningham-Atkins et al., 2004), the correlation between the quantity of discussion forum contributions and sense of community (Dawson, 2006), the difference in course grade between face-to-face and online discussion group members (Cifuentes, 2003), stages of interaction demonstrated in the discussion messages (Akarasriworn \& Ku, 2013), the correlations between various interaction items on the classroom community scale (Shackelford \& Maxwell, 2012), the difference in participation levels of students from different cultural backgrounds (Giannini-Gachago \& Seleka, 2005), the correlations between students' perceptions of online discussion quality and contributing factors (Du \& Xu, 2012), and other variables appropriate for numerical measurements.

Qualitative methods were applied to investigate discursive political moves such as establishing status and building solidarity during collaborative asynchronous online dialogue journaling (Bryce, 2007), the theoretical constructs demonstrated in developing an effective online learning community (Lee et al., 2006), the types of interaction that occurred among the students (Sorensen \& Baylen, 2004), the levels of thinking exhibited in a graduate course-required online discussion (Christopher et al., 2004), events to follow each type of interaction (Jeong, 2003), the potential differences between similar online courses and face-to-face courses (Lobel et al., 2005), the mechanisms of establishing and maintaining common ground in electronic discussion (Mäkitalo et al., 2002), types of conditions that are likely to lead to a higher level of performance and a higher quality of understanding (Ellis, et al., 2006), the social dynamics in an online discussion group (Çelik, 2013), and other discursive and thematic topics.

The fact that qualitative methods were applied in more studies than quantitative methods could be an indication of the complexity of the topic. In many studies, the qualitative data were quantified for analysis and presentation of the findings (Ahern \& El-Hindi, 2000; Brooks \& Bippus, 2012; Fernandez, 2007; Huang \& Nakazawa, 2010; Lapadat, 2007; Maushak \& Ou, 2007; Pilkington \& Walker, 2003; Thomas, 2002; Xie \& Ke, 2011); however, only one mixed-methods study (Exter et al., 2009) was found during the search, indicating a potential direction for future research. In many recent studies, social network analysis was applied to generate findings from a new perspective. This could also be a new direction for future research.

\section{Participants’ Interactions}

Regarding the third research question, the primary findings were extracted, summarized, and analyzed using constant comparison coding technique. Through such process, four main categories and eight sub-categories of interaction aspects emerged from the comparison. Although the primary studies were conducted over a range of more than fifteen years, many of the findings complemented or echoed each other, indicating that the characteristics and patterns of the participation and interactions changed little over time, as did the major contributing factors.

In order to synthesize the findings from various studies, "participation" is defined as voluntary presence in an Internet-mediated discussion, including the mandatory presence under a course requirement. Twenty-two studies reported findings related to students' participation. These findings were categorized as related to participation instead of interaction because the measurements in these studies were largely 
taken by counting the number of messages read and/or posted during the online discussions, the length of messages, and frequency of participants logging into the supporting platforms. These actions typically involved only one participant and did not consider any reaction to the action, which was the distinguishing difference between participation and interaction. Eleven of the 22 studies described characteristics of participation. Some of the examples of these characteristics included:

- A few students dominate the discussion (Çelik, 2013; Gerbic, 2006; Giannini-Gachago \& Seleka, 2005; Picciano, 2002);

- The students who do not often talk in face-to-face classroom participated more in online discussion (Ahern \& El-Hindi, 2000; Larson \& Keiper, 2002);

- Limited and low level participation at the beginning of the online discussion (Gerbic, 2006; Giannini-Gachago \& Seleka, 2005; Thomas, 2002);

- Increasing participation as the online discussion progressed (Bryce, 2007; CunninghamAtkins et al., 2004; Thomas, 2002);

- The participation level varied widely among the participants (Çelik, 2013; CunninghamAtkins et al., 2004; Giannini-Gachago \& Seleka, 2005; Poole, 2000).

In addition, eighteen studies tested or analyzed contributing factors related to the measurements of participation. Examples of the contributing factors include:

- The most influential factor for participation was the connection to grades (Gerbic, 2006) ;

- Students in online classes participated more actively than students in face-to-face classes (Lobel, 2005; Pilkington \& Walker, 2003)

- Students with previous or current face-to-face experience with peers participated more actively in online discussion than those without face-to-face experience with such peers (Brooks \& Bippus, 2012)

- Feedback and involvement from the instructor and teaching assistant were related to higher levels of student participation (Wuttikietpaiboon, 2012);

- Participation varied by gender (Cheng et al., 2012; Im, 2004);

- Participants taking assigned or predetermined roles such as moderator or manager showed higher levels of participation (Pilkington \& Walker, 2003; Poole, 2000; Xie et al., 2014);

- The mix of cognitive styles in a group might influence activity level (Cunningham-Atkins et al., 2004).

Interaction is defined in this synthesis as events involving two parties' actions, including both reading and posting messages during the online discussions. Measurements of interactions were largely taken by the following two methods: one approach used was to count the layers of the messages responding to each other, similar to the methods utilized by Sorensen \& Baylen (2004); the other trend was to analyze the meanings demonstrated in the posted text to the degree of thinking and/or cognition, similar to the methods proposed and utilized by Gunawardena (1997) and Bloom's (1956) taxonomy. Although these two methods of measuring are rather different, they could both be translated to degrees or levels categorized as "low," "medium," and "high." The findings related to the content of the interactions from the primary studies were coded into reflecting "low," "medium," or "high" interaction before synthesizing.

Twenty-one of the 42 primary studies described characteristics of participants' interactions. These characteristics formed a sketch of the "reciprocal events" (Wagner, 1994) in the particular context of coursework in higher education settings. Some examples of such found characteristics include: 
- The interactions were generally collaborative and constructive (Giannini-Gachago \& Seleka, 2005; Maushak \& Ou, 2007) with some off-topic messages (Cifuentes, 2003; Light et al., 2000);

- Low to medium level interactions dominated the discussion with some high level evolving later (Akarasriworn \& Ku, 2013; Davidson-Shivers et al., 2000; Fernandez, 2007; Gerbic, 2006; Im, 2004; Jeong, 2003; Larson \& Keiper, 2002; Mäkitalo et al., 2002; Poole, 2000; Sorensen \& Baylen, 2004; Thomas, 2002; Xie \& Ke, 2011);

- More interaction in the form of response than initiation, but some initiations received no response (Jeong, 2003; Larson \& Keiper, 2002; Lee et al., 2006; Poole, 2000; Thomas, 2002);

- The interactions rarely indicated challenging, disagreeing, or evaluating arguments (Jeong, 2003; Maushak \& Ou, 2007; Sorensen \& Baylen, 2004);

- Some degree of social bond dominated synchronous chat but was rarely observed in asynchronous discussion (Im, 2004);

- Some participants dominated higher level interactions, while other participants remained at lower level interactions (Christopher et al., 2004);

- Interactions with supportive messages dominated the discussions (Jeong, 2003; Sorensen \& Baylen, 2004);

- The participants tended to give direct answers (Lee et al., 2006);

- It was difficult to detect emotion during the discussion (Larson \& Keiper, 2002; Poole, 2000).

Seventeen studies reported contributing factors promoting higher degree or level of interaction. Regarding Wagner's (1994) definition of interaction, these contributing factors outlined how the involving parties "mutually influence one another" (p.8). Examples of such found characteristics include:

- Asynchronous discussions were more structured and cohesive than synchronous discussions (Bryce, 2007; Fernandez, 2007; Im, 2004);

- The instructor's involvement was related to higher levels of interaction (Light et al., 2000; Xie \& Ke, 2011);

- Intrinsic motivation influenced the individual's level of interaction (Xie \& Ke, 2011);

- There was a relationship between the degree of learner-learner interactions and students' perceived sense of community (Dawson, 2006);

- Arguments were likely to generate additional arguments and disagreement and then lead to higher levels of interaction (Jeong, 2003);

- Understanding the purpose of the discussion and posting questions promoted higher level interactions (Ellis et al., 2006; Lapadat, 2007);

- There was a positive relationship between level of interaction and time spent on discussion (Sorensen \& Baylen, 2004).

Eight studies analyzed student-students interactions and/or student-instructor interactions following Moore's (1989) model of interaction in distance learning. The other two categories, studentcontent interaction and learner-interface interaction, were not reported in these primary studies. Two main themes emerged from findings across these studies:

- Student-teacher interactions dominated at the beginning of the discussion but decreased over the course of the discussion (Huang et al., 2010; Light et al., 2000; Pilkington \& Walker, 2003);

- The frequency of student-student interactions may have been low at the beginning but increased significantly over the course of the discussion to surpass student-teacher interactions (Ahern \& El-Hindi, 2000; Exter et al., 2009; Huang et al., 2010; Poole, 2000) 
It is worth noticing that the numbers of studies investigating students' perceptions and performances are both relatively low, indicating a need for more empirical studies on these topics. Students' perceptions regarding online discussion were reported in eight studies. Several similar findings from multiple studies showed the contributing factors for students' positive perception toward online discussion and/or online course. Some examples include the sense of community (Exter et al., 2009; Fernandez, 2007; Lee et al., 2006), constructivist environment (Exter et al., 2009; Lapadat, 2007), supportiveness (Çelik, 2013; Lapadat, 2007), evaluation (Lee et al., 2006; Morris, 2010), and instructor involvement and support (Lee et al., 2006; Morris, 2010). Students' course performances during and after the online discussion experience were reported in five studies. The findings include:

- The use of assessment rubrics encouraged students' participation and achievement (Wuttikietpaiboon, 2012);

- Students participating in online discussion outperformed those participating only in face-toface discussion (Campbell et al., 2008);

- Participation in online discussion promoted writing performance (Picciano, 2002);

- Both active and reflective learners performed better as a result of participation in online discussion (Zhan et al., 2011);

- Kinesthetic intelligence and interpersonal intelligence were negatively affected by online discussion (Cifuentes, 2003).

In addition to the four main categories and eight sub-categories of interaction aspects, one subtle pattern also emerged among the selected primary studies - the potential relationship between the specificity of the discussion instruction and the quality of the discussion. In 36 of the 42 primary studies, online discussion participation was reported to be mandatory. Among these 36 studies, twenty-five reported discussion requirements on participation quantity, e.g., frequency and length of discussion posts, and/or grading scale of participation. Seven of the 25 studies reported various degrees of requirement and/or instruction on the quality of discussion, e.g., the content expectation and indicators of critical thinking. Within the 18 studies reporting requirements only on participation quantity, two reported higher level of critical thinking or cognitive engagement; within the seven studies reporting requirements on both participation quantity and quality, two reported higher level of critical thinking or cognitive engagement. This distribution and comparison is illustrated in Figure 1 (next page). Such contrast seems to indicate a potential relationship between specific instructions and/or requirements on the quality of discussion and higher levels of critical thinking or cognitive engagement as demonstrated in the discussion.

\section{Holistic Representation of the Participants’ Interactions}

To answer the last research question, the coded findings were connected back to other parameters reported in the primary studies, such as course topic, format, grouping scale, instructor involvement, grading, and participants. Similar and contradicting findings from different studies were compared for potentially related parameters. Several noteworthy points emerged from this comparison:

- Studies conducted in undergraduate courses generated more findings on participation and lower level peer interaction, while studies conducted in graduate courses generated more findings on interaction levels and predictors;

- All but one study were conducted within one academic year, which might have limited the potential for more higher level interactions to emerge;

- Five studies reported that learner-instructor interactions were highly valued, indicating potential interventions for future research. 

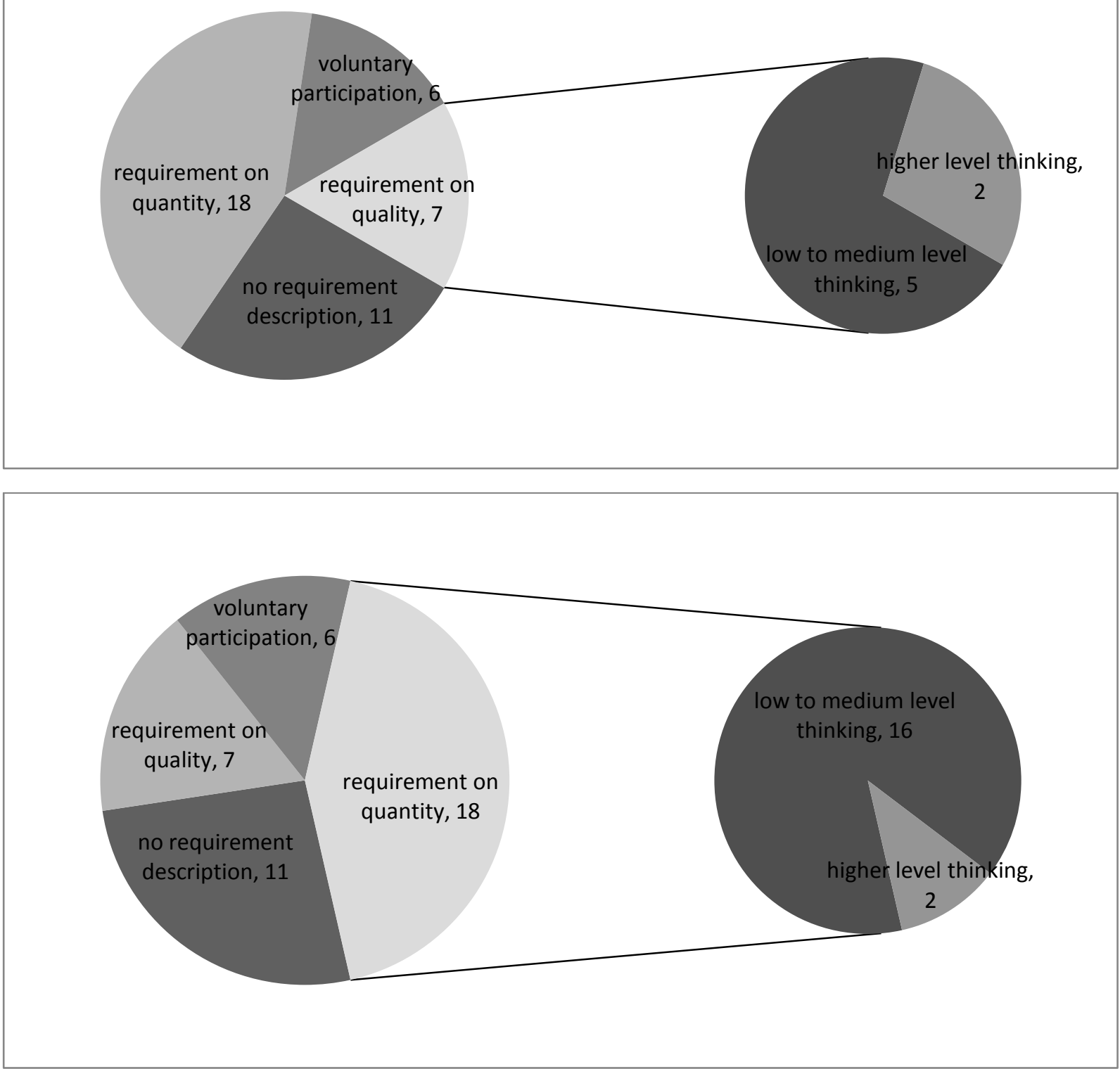

Figure 1. Comparison of levels of thinking following different levels of discussion requirement

The next step of synthesis took into consideration all of the reported parameters. Similar and complementary findings from multiple studies conducted in various contexts were compared and connected. For example, 12 studies reported to varying degrees that the online discussion being examined began with low- to medium-level interactions while higher level interactions were observed in the later stage of the discussions (Akarasriworn \& Ku, 2013; Davidson-Shivers et al., 2000; Fernandez, 2007; Gerbic, 2006; Im, 2004; Jeong, 2003; Larson \& Keiper, 2002; Mäkitalo et al., 2002; Poole, 2000; Sorensen \& Baylen, 2004; Thomas, 2002; Xie \& Ke, 2011). A closer examination of the contexts of these studies revealed that these 12 studies spanned a 14-year range, from 2000 to 2013, in four different countries with undergraduate and graduate students in five different academic disciplines. When studies conducted in such diverse contexts report similar findings, it is reasonable to consider that similar 
findings have a high probability of existing in other contexts. Nine such themes from similar or complementary findings emerged from the synthesis:

- Participation was the foundation for interaction;

- Instructor support and feedback (including assessment) was highly valued, and over time affected students' participation and peer interaction quality and quantity;

- Peer interactions started slowly with frequent off-task and disruptive posts;

- The majority of peer interactions initially involved responding to an assignment, followed by supporting and constructive posts, with less dialogue and, rarely, challenging posts;

- Interactions between students and instructor were overall less than peer interactions, and decreased over time while peer interactions stayed consistent;

- Assigned student leaders and/or moderators affected the quality and quantity of discussion;

- Perceived self-competency and intrinsic motivation led to higher quantity and quality interaction, which might relate to taking a dominating or leading role;

- Level of familiarity and relatedness to peers, environment, and discussion topics led to higherlevel peer interaction;

- The dynamics of interaction varied among groups, and was related to collaborative assignments, the existence of highly motivated members and higher-level elaboration, and the opportunity for members to contribute.

These themes illustrate a progression of Internet-mediated discussion as part of coursework in higher education settings. Such progress can be represented in the following figure.

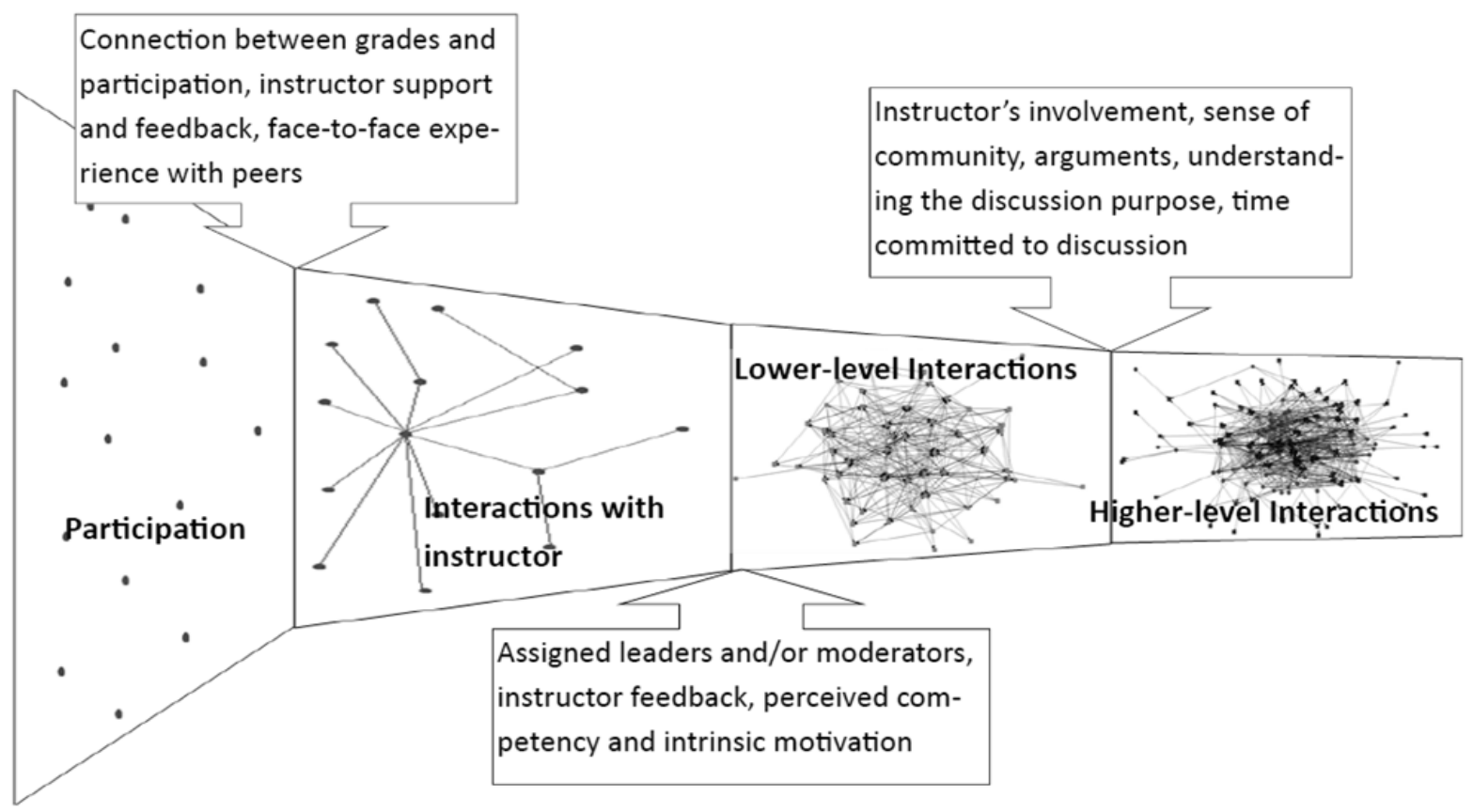

Figure 2. Illustration of a holistic process of Internet-mediated discussion 
As a form of computer-mediated communication, Internet-mediated discussion showed its unique characteristics when utilized in higher education settings as part of coursework. Two stages of communication are clearly present. The first stage is participation, which is a one-way communication. The second stage is interaction, which is a two-way communication. The development of these two stages is based on student participation, which begins with interactions with the instructors or assigned leaders, increases to more lower-level peer interactions with support and feedback from the instructors and/or leaders/moderators, and gradually progresses to more higher-level interactions with several core participants and fading instructor support.

\section{Summary}

The process of synthesizing current research about online discussion in higher education settings revealed several key findings:

- The most heavily represented academic field where the primary studies were conducted was education, as reported in thirteen studies; healthcare and mathematics were each reported in only one study; and some commonly offered academic disciplines were not represented in the body of research, such as law, arts, political science, and engineering. This distribution could mean that either the Internet-mediated discussion component had not been widely applied in some of the academic disciplines in higher education settings, or that researchers had not paid adequate attention to certain areas.

- The fact that qualitative methods were applied in more studies than quantitative methods could be an indication of the complexity of the topic. There was only one mixed-methods study (Exter et al., 2009) in the 42 primary studies, indicating a potential direction for future research. Social network analysis was applied in many recent studies to generate findings from a new perspective. This could also be a new direction for future research.

- It is worth noting that the numbers of studies investigating students' perceptions and performances are both relatively low, indicating a need for more empirical studies on these topics.

- The contrast of higher level critical thinking and cognitive engagement in online discussion with different degree of specificity seems to indicate a potential relationship between the instructions and/or requirements on the quality of discussion and level of critical thinking or cognitive engagement demonstrated in the discussion.

\section{Discussions}

\section{Limitation}

There are three limitations to this review. Although the search for the empirical studies was systematic and extensive, it was not exhaustive. It is reasonable to assume that many studies qualifying for inclusion in this analysis have not been located. However, the included 42 studies show a vast diversity in the time of publication, geological location, participants' academic level and discipline area, and the analysis methodologies applied. Therefore, it is reasonable to assume that the included pool of studies is representative of the body of existing literature.

Such diversity of the primary studies also makes it difficult to find multiple studies reporting similar or complementary findings from various contexts. The numerous and diverse variables addressed in these studies precluded the direct comparison and analysis of conflicting findings. For this reason, some findings reported in only one study versus conflicting findings from two studies conducted in different contexts were not considered as thematic findings in this review. 
The objective of this review was to construct a more comprehensive understanding of the participants' interactions in Internet-mediated discussion when such discussions were utilized as components of formal courses in higher education settings. Such an objective requires a certain degree of generalization from the primary studies. However, only three primary studies were conducted within quasi-experimental settings (Campbell et al., 2008; Cifuentes, 2003; Exter et al., 2009) to warrant generalizability, while the majority of the primary studies should be interpreted with careful consideration of their different contexts. In order to reach the objective of this review, findings from the primary studies had to be examined closely along with the contextual data accompanying each finding. Such constraints limited findings from the primary studies that could be weighted in the findings of this review.

\section{Strength and significance}

This systematic review and synthesis is based on over 14 years of high quality empirical research that covers a diverse range of perspectives. Many of the findings from one study can be compared to or connected with findings from other studies to generate new meanings and to promote further interpretation. This process is similar to constructing a building with various blocks. By doing so, this review extends the implications of all included primary studies to a broader context.

Even with the aforementioned limitations, this review achieved its main objective of developing a foundation for comprehensive understanding of participants' interactions in Internet-mediated discussion, thus filling a gap in existing literature. Meanwhile, this review also points to several potential directions for future research, which can be beneficial to researchers as well as practitioners in the field of higher education.

\section{Conclusion}

This systematic review synthesizes findings from primary studies on participants' interactions in Internet-mediated discussions as higher education course components. Four categories and eight subcategories emerged from the analysis, indicating several potential directions for future research. The findings from the primary studies were connected to illustrate the progress of interactions developing in the course of the discussion. Such an illustration provides a comprehensive understanding on the overall phenomena of utilizing online discussion as a course component in higher education settings. Researchers, practitioners, students, and administrators may all benefit from this newly constructed understanding.

\section{References}

References marked with an asterisk indicate studies included in the synthesis.

*Ahern, T. C. \& El-Hindi, A. E. (2000). Improving the instructional congruency of a computer-mediated small-group discussion: A case study in design and delivery. Journal of Research on Computing in Education, 32(3), 385-400.

*Akarasriworn, C., \& Ku, H. (2013). Graduate students' knowledge construction and attitudes toward online synchronous videoconferencing collaborative learning environments. Quarterly Review of Distance Education, 14(1), 35-48.

Bates, A. T. (2004). Technology, e-learning and distance education (2nd ed.). London: Routledge.

Bloom, B. S. (1956). Taxonomy of Educational Objectives: Handbook of Cognitive Domain. New York: McKay. 
A Systematic Review of Empirical Studies on Participants' Interactions on Internet-Mediated Discussion Board as Course Component in Formal Higher Education Settings

*Brannan, T. A. (2005). Learner interactivity in higher education: comparing face-to-face, hybrid, and online instruction. Distance Learning, 2(2), 1-8.

*Brooks, C. F., \& Bippus, A. M. (2012). Underscoring the social nature of classrooms by examining the amount of virtual talk across online and blended college courses. European Journal of Open, Distance and E-Learning, (1).

*Bryce, N. (2007). Online dialogue journaling in graduate literacy teacher education: Identity and knowledge construction. Orlando: Int Inst Informatics \& Systemics.

*Campbell, M., Gibson, W., Hall, A., Richards, D., \& Callery, P. (2008). Online vs. face-to-face discussion in a web-based research methods course for postgraduate nursing students: A quasiexperimental study. International Journal of Nursing Studies, 45(5), 750-759.

* Çelik, S. (2013). Unspoken social dynamics in an online discussion group: The disconnect between attitudes and overt behavior of English language teaching graduate students. Educational Technology Research and Development, 61(4), 665-683.

*Cheng, S. S., Liu, E. Z. F., Chen, N. S., Shih, R. C., \& Chang, C. S. (2012). Gender differences in college students' behaviors in an online question-answer discussion activity. Asia-Pacific Education Researcher, 21(2), 244-256.

*Christopher, M. M., Thomas, J. A., \& Tallent-Runnels, M. K. (2004). Raising the bar: encouraging high level thinking in onlinediscussion forums. Roeper Review, 26(3), 166-171.

*Cifuentes, L. J. (2003). The interactive effects of computer conferencing and multiple intelligences on expository writing. Quarterly Review of Distance Education, 4(1), 15-30.

Corbin, J., \& Strauss, A. (Eds.). (2008). Basics of qualitative research: Techniques and procedures for developing grounded theory. Thousand Oaks: Sage.

*Cunningham-Atkins, H., Powell, N., Moore, D., Hobbs, D., \& Sharpe, S. (2004). The role of cognitive style in educational computer conferencing. [Article]. British Journal of Educational Technology, 35(1), 69-80.

*Davidson-Shivers, G. V., Luyegu, E., \& Kimble, B. E. (2012). An analysis of asynchronous discussions: A case study of graduate student participation in online debates. Journal of Educational Multimedia and Hypermedia, 21(1), 29-51.

*Dawson, S. (2006). Online forum discussion interactions as an indicator of student community. Australasian Journal of Educational Technology, 22(4), 495.

*Du, J., \& Xu, J. (2010). The quality of online discussion reported by graduate students. Quarterly Review of Distance Education, 11(1), 13-61.

*Ellis, R. A., Goodyear, P., Prosser, M., \& O'Hara, A. (2006). How and what university students learn through online and face-to-face discussion: conceptions, intentions and approaches. Journal of Computer Assisted Learning, 22(4), 244-256.

*Exter, M. E., Korkmaz, N., Harlin, N. M., \& Bichelmeyer, B. A. (2009). Sense of community within a fully online program: Perspectives of graduate students. Quarterly Review of Distance Education, 10(2), 177-251. 
A Systematic Review of Empirical Studies on Participants' Interactions on Internet-Mediated Discussion Board as Course Component in Formal Higher Education Settings

*Fernandez, M. L. (2007). Communication and instruction in an online graduate education course. Teaching Education, 18(2), 137-150.

*Giannini-Gachago, D., \& Seleka, G. (2005). Experiences with international online discussions: Participation patterns of Botswana and American students in an Adult Education and Development course at the University of Botswana. International Journal of Education \& Development using Information \& Communication Technology, 1(2), 163-184.

*Guilar, J. D., \& Loring, A. (2008). Dialogue and community in online learning: lessons from Royal Roads University. Part of a special issue on instructional design, 22(3), 19-40.

Gunawardena, C. N., Lowe, C. A., \& Anderson, T. (1997). Analysis of a global online debate and the development of an interaction analysis model for examining social construction of knowledge in computer conferencing. Journal of educational computing research, 17(4), 397-431.

Hillman, D. C., Willis, D. J., \& Gunawardena, C. N. (1994). Learner-interface interaction in distance education: An extension of contemporary models and strategies for practitioners. American Journal of Distance Education, 8(2), 30-42.

*Huang, W. D., \& Nakazawa, K. (2010). An empirical analysis on how learners interact in wiki in a graduate level online course. Interactive Learning Environments, 18(3), 233-244.

*Im, Y. L. (2003). Pedagogical implications of online discussion for preservice teacher training. Journal of Research on Technology in Education (International Society for Technology in Education), 36(2), 155-170.

*Jeong, A. C. (2003). The sequential analysis of group interaction and critical thinking in online. American Journal of Distance Education, 17(1), 25-43.

*Lapadat, J. C. (2007). Discourse devices used to establish community, increase coherence, and negotiate agreement in an online university course. Journal of Distance Education, 21(3), 59-91.

*Larson, B. E., \& Keiper, T. A. (2002). Classroom discussion and threaded electronic discussion: learning in two arenas. Contemporary Issues in Technology and Teacher Education, 2(1), 45-62.

*Lee, J., Carter-Wells, J., Glaeser, B., Ivers, K., \& Street, C. (2006). Facilitating the development of a learning community in an online graduate program. Quarterly Review of Distance Education, 7(1), 13-33.

*Lee, J., \& Gibson, C. C. (2003). Developing self-direction in an online course through computermediated interaction. American Journal of Distance Education, 17(3), 173-187.

*Light, V., Nesbitt, E., Light, P., \& Burns, J. R. (2000). 'Let's you and me have a little discussion': computer mediated communication in support of campus-based university courses. Studies in Higher Education, 25(1), 85-96.

*Lobel, M., Neubauer, M., \& Swedburg, R. (2005). Selected topics from a matched study between a faceto-face section and a real-time online section of a university course. International Review of Research in Open \& Distance Learning, 6(2).

*Mäkitalo, K., Häkkinen, P., Leinonen, P., \& Järvelä, S. (2002). Mechanisms of common ground in casebased web discussions in teacher education. The Internet and Higher Education, 5(3), 247-265. 
A Systematic Review of Empirical Studies on Participants' Interactions on Internet-Mediated Discussion Board as Course Component in Formal Higher Education Settings

*Maushak, N. J., \& Ou, C. (2007). Using synchronous communication to facilitate graduate students' online collaboration. Quarterly Review of Distance Education, 8(2), 161-169.

Moore, M. G. (1989). Three types of interaction. American Journal of Distance Education, 3(2), 1-6.

*Morris, T. A. (2010). Exploring community college student perceptions of online learning. International Journal of Instructional Technology and Distance Learning 8(6), 31-43 (2011).

*Picciano, A. G. (2002). Beyond student perceptions: Issues of interaction, presence, and performance in an online course. Journal of Asynchronous learning networks, 6(1), 21-40.

*Pilkington, R. M., \& Walker, S. A. (2003). Facilitating debate in networked learning: Reflecting on online synchronous discussion in higher education. Instructional Science, 31(1/2), 41-63.

*Poole, D. M. (2000). Student participation in a discussion-oriented online course: a case study. Journal of research on computing in education, 33(2), 162-177.

*Shackelford, J. L., \& Maxwell, M. (2012). Sense of community in graduate online education: Contribution of learner to learner interaction. International Review of Research in Open and Distance Learning, 13(4), 228-249.

*Sorensen, C. K., \& Baylen, D. M. (2004). Patterns of communicative and interactive behavior online: Case studies in higher education. Quarterly Review of Distance Education, 5(2), 117-126.

*Thomas, M. J. W. (2002). Learning within incoherent structures: the space of online discussion forums. Journal of Computer Assisted Learning, 18(3), 351-366.

Thurlow, C., Lengel, L., \& Tomic, A. (2004). Computer mediated communication. London: Sage.

Wagner, E. D. (1994). In support of a functional definition of interaction. American Journal of Distance Education, 8(2), 6-29.

*Wise, A. F., Perera, N., Hsiao, Y. T., Speer, J., \& Marbouti, F. (2012). Microanalytic case studies of individual participation patterns in an asynchronous online discussion in an undergraduate blended course. Internet and Higher Education, 15(2), 108-117.

*Wuttikietpaiboon, K. (2012). Engaging graduate students in rich asynchronous online discussions. In L. G. Chova, A. L. Martinez \& I. C. Torres (Eds.), Inted2012: International Technology, Education and Development Conference (pp. 4356-4365). Valenica: Iated-Int Assoc Technology Education a\& Development.

*Xie, K., \& Ke, F. (2011). The role of students' motivation in peer-moderated asynchronous online discussions. British Journal of Educational Technology, 42(6), 916-930.

*Xie, K., Yu, C., \& Bradshaw, A. C. (2014). Impacts of role assignment and participation in asynchronous discussions in college-level online classes. Internet and Higher Education, 20, 1019.

*Zhan, Z. H., Xu, F. Y., \& Ye, H. W. (2011). Effects of an online learning community on active and reflective learners' learning performance and attitudes in a face-to-face undergraduate course. Computers \& Education, 56(4), 961-968. 